\author{
Sergey Nikulin and Viacheslav Misin
}

\title{
TECHNOLOGICAL AND ECOLOGICAL ASPECTS OF THE PRACTICAL APPLICATION OF QUATERN ARY AMMONIUM SALTS IN PRODUCTION OF SYNTHETIC EMULSION RUBBERS IN RUSSIA
}

\author{
N. M . Emanuel Institute of Biochemical Physics, Russian Academy of Sciences \\ 4, Kosygina str., 119334 M oscow, Russia \\ misin@sky.chph.ras.ru
}

Received: N ovember 26, 2007

\begin{abstract}
In the review physical and chemical aspects and technological parameters of the rubbers production processes from industrial latex with application of ammonium halogenides, tetraalkylammonium salts, poly- $(\mathrm{N}, \mathrm{N}-$ dimethyl-2-oxypropyleneammonium) chloride, poly-N,Ndimethyl-N,N-diallylammonium chloride, and his copolymer with $\mathrm{SO}_{2}$ are considered. A significant ecological effect of polymeric flocculants application is shown.
\end{abstract}

Key words: quaternary ammonium salts, rubber, latex, flocculants, ecology.

\section{Introduction}

Coagulation of the rubber emulsion is one of the main stages during production of synthetic emulsion rubbers. A routine and quite efficient way of emulsion rubbers extraction from latexes is the application of inorganic salts (first of all $\mathrm{NaCl}$ ) under acidification of the coagulating system with a mineral acid [1]. It is known that for coagulation of 1 ton of the industrial emulsion of different rubbers (butadiene-styrene, butadiene-nitrile, polybutadiene ones or others) a required quantity of $\mathrm{NaCl}$ is from 250 to $1500 \mathrm{~kg}$. Mineral salts in the process of wastewater treatment at waste disposal plants are not decomposed and entrapped but drained to the natural wells. This results in pollution of the environment, soil, and drinking water salinization. For example, if production capacity of emulsion butadiene-styrene rubbers is of 100000 tons per year waste discharge of salts in the form of aqueous solution attains 30000 tons per year just from the extraction workshops. Thus, at emulsion rubbers production the annual waste discharge from the extraction workshops to the natural wells is of hundred thousand tons of $\mathrm{NaCl}$ and other salts, causing an irreversible ecological damage.

The most efficient way of perfection of the rubbers from latexes extraction technology is the elaboration of brand new coagulating agents providing a decrease of salt components consumption or their complete elimination from the technological process. Such coagulating agents can be water-soluble ammonium salts, particularly quaternary ammonium salts (QAS).

However, only in Russia a full-scale investigation work in the field has been made including:

- the study of physical-chemical processes of latexes coagulation for industrial rubbers production with the use of cationic polyelectrolytes;

- the study of rubbers properties, their mixtures, and vulcanizates;

- applied investigations of possible application of cationic polyelectrolytes in industry.

Previously, flocculation mechanisms of polystyrene latexes [2-4] and some rubbers [4-7] with the use of QAS were investigated. However, the works aimed at solving the chemical and technological problems of the industrial production of synthetic emulsion rubbers were made later in Russia.

This article presents the results of the investigations conducted by the authors concerning the application of different QAS as coagulating and flocculating agents of the industrial latexes used in the production of synthetic rubbers. The works that are directly aimed at the elaboration of the new approaches to the technology of extraction of synthetic rubbers from butadiene-styrene latexes are considered in most details.

According to the abbreviations accepted in Russia emulsion rubbers are denoted as follows:

- SKS-30 - butadiene-styrene rubber (styrene content is $30 \%$ );

- SKMS-25 - butadiene-( $\alpha$-methyl) styrene rubber (styrene content is $25 \%$ );

- EPB - emulsion polybutadiene;

- SKN-26 SM - butadiene-nitrile rubber (acrylonitrile content is $26 \%$ );

- Letters A, R, K, P, M, O, C after the numbers denote: $\mathrm{A}$ - a rubber of low-temperature polymerization, $\mathrm{R}$ - regulated, $\mathrm{K}$ - colophony emulsifier, $\mathrm{P}$ - waxed emulsifier, $\mathrm{M}$ - oil-filled, $\mathrm{O}$ - oxide-filled, and $\mathrm{C}$ - carbonfilled (technical carbon). 


\section{Results and Discussion}

\subsection{Low-molecular ammonium salts}

In [8] a reduction of coagulating activity of ammonium halogenides was observed in a series of $\mathrm{NH}_{4} \mathrm{~F}>\mathrm{NH}_{4} \mathrm{Cl}>\mathrm{NH}_{4} \mathrm{Br}>\mathrm{NH}_{4} \mathrm{~J}$ for the discharge intensity of these salts equal to $20,25,50$ and $100 \mathrm{~kg} /$ ton of rubber $(\mathrm{pH}=2.5-3.0$; temperature is $333 \mathrm{~K})$. Efficiency of SKS-30 ARK and ARKPN rubber extraction from latexes in the presence of $\mathrm{NH}_{4} \mathrm{Cl}$ under the influence of different parameters was studied in details in [9]. The analysis of the rubber properties as well as compounded rubbers and vulcanizing agents on their basis demonstrated that these properties do not change in fact under the change of the commonly applied coagulating agent $\mathrm{NaCl}$ by $\mathrm{NH}_{4} \mathrm{Cl}$ (see Table 1).

Using SKS-30 ARKP and SKS-30 ARK latexes as an example it was shown $[10,11]$ that with the use of
$\mathrm{Me}_{4} \mathrm{NCl}, \mathrm{Et}_{4} \mathrm{NCl}, \mathrm{Et}_{4} \mathrm{NBr}$ and $n-\mathrm{Bu}_{4} \mathrm{NI}$ a complete coagulation of latex can be achieved for the consumption standards of $60-150 \mathrm{~kg} / \mathrm{ton}$ of rubber. These values are 2-5 times less than the consumption standard for the industrial coagulating agent $-\mathrm{NaCl}$.

In general, coagulating ability of all the lowmolecular salts was not very high.

\subsection{Mixtures of the routine coagulating agents with poly- $\mathrm{N}, \mathrm{N}$-dimethyl-N,N- diallylammonium chloride}

By the example of SKS-30 ARKP (ARK, AKO, ARKM) and butadiene-( $\alpha$-methyl) styrene latexes SKMS30 ARKP (ARK, ARKM) of industrial rubbers [12-15] it was shown that addition of PDMDAACl to the routine coagulating agents ( $\mathrm{NaCl}$, leather glue, protein hydrolyzate) created the following advantages:

Table 1

Properties of SKS-30 ARKPN rubbers extracted with the use of $\mathrm{NaCl}$ and $\mathrm{NH}_{4} \mathrm{Cl}$ as well as rubber compounds and rubber resins

\begin{tabular}{|c|c|c|}
\hline \multirow{2}{*}{ Quality performance } & \multicolumn{2}{|c|}{ Coagulating agents } \\
\hline & $\mathrm{NaCl}$ & Ammonium chloride \\
\hline Mooney viscosity & 45 & 46 \\
\hline Conditional toughness under stretching, $\mathrm{MPa}$ & $25.0 / 26.9$ & $27.5 / 26.9$ \\
\hline Relative extension under fracture, $\%$ & $690 / 670$ & $675 / 650$ \\
\hline Relative residual deformation after fracture, $\%$ & $16 / 18$ & $14 / 16$ \\
\hline Rebound elasticity, \% & $42 / 40$ & $41 / 39$ \\
\hline Content of antioxidant (Agidol-2), $\%$ & $1.0 / 1.0$ & $1.2 / 1.0$ \\
\hline Mass fraction of organic acids, $\%$ & 4.92 & 6.06 \\
\hline Mass fraction of saponaceous organic acids, $\%$ & 0.16 & 0.05 \\
\hline Loss of mass under drying, $\%$ & 0.17 & 0.12 \\
\hline Mass fraction of the bound styrene, $\%$ & 22.5 & 22.5 \\
\hline
\end{tabular}

- a long-term preservation of protein coagulating agents in aqueous solutions at $293-295 \mathrm{~K}$ without their decomposition and appearance of unpleasant smells;

- a part of each of the coagulating agents in a composition of 2- or 3-component mixture was considerably less than in case of their individual usage, resulting in 1.5-2.0 time reduction in a leather glue consumption;

- application of NaCl- PDMDAACl mixtures enabled a 5-10 times $\mathrm{NaCl}$ consumption reduction to the values of $20-50 \mathrm{~kg} /$ ton of rubber;

- complete coagulation was attained in a wider range of $\mathrm{pH}$ values $\mathrm{pH}=2.5-4.5$ making it possible to reduce consumption of $\mathrm{H}_{2} \mathrm{SO}_{4}$ from $15-18$ to $8-12 \mathrm{~kg} / \mathrm{ton}$ of rubber;

- consumption rate of PDMDAACl was $0.4-1.2$ $\mathrm{kg} /$ ton of rubber;

- the extracted rubbers satisfied the Standard of the USSR (GOST) and technical specifications (TU) requirements for the corresponding grade marks of rubbers;

- the properties of the vulcanizates did not yield to the properties of the check samples.

All of the oil-filled rubbers and their vulcanizates satisfied the requirements of the Russian national standards for the corresponding grade marks of rubbers $[13,14]$. The role of PDMDAACl was decisive in the experiments; increasing the dosage of PDMDAACl to more than $2 \mathrm{~kg} /$ ton of rubber demonstrated the possibility of complete elimination of $\mathrm{NaCl}$ from application.

\subsection{Poly- $\mathrm{N}, \mathrm{N}$-dimethyl- $\mathrm{N}, \mathrm{N}$ - diallylammonium chloride}

Since according to [12-15] individual PDMDAACl is an efficient flocculating agent for the industrial emulsions of rubbers a large amount of investigations concerning the influence of different parameters (latex and coagulating 
agent concentrations, polyelectrolyte consumption and its molecular mass, temperature of the process) on the process of extraction and on the properties of different rubber grade marks - SKS and SKMS was performed. The rubbers extracted with the use of $\mathrm{NaCl}$ were used as the reference samples [15-20].

The mass of the extracted coagulum was shown to increase with the increase of PDMDAACl amount added to the latex $[17,18]$. Flocculation completeness was achieved for the consumption rate of PDMDAACl $\approx$ $\approx 4 \mathrm{~kg} /$ ton of rubber and application rate of $\mathrm{H}_{2} \mathrm{SO}_{4} \approx$ $\approx 15 \mathrm{~kg} /$ ton of rubber. Here the application rate of cationic polyelectrolyte required for attaining of a complete SKS-30 ARK latex coagulation depends on the temperature: an optimal coagulation temperature was $333 \mathrm{~K}$. The application of higher temperatures did not result in a considerable increase of a coagulum yield. For the temperatures of 293 and $353 \mathrm{~K}$ flocculation curves did not in fact depend on the value of PDMDAACl molecular mass (172000, 62000 and 16000). The concentration of the initial aqueous solution of cationic polyelectrolyte did not have any considerable effect on its consumption rate necessary for complete extraction of rubber from latex.

The extracted rubbers very slightly differed from the check samples by their chemical composition and satisfied the requirements of the Russian standards. The main quality coefficients of vulcanizates on the basis of the experimental and check samples were equivalent (see Table 2). However, rubber compounds on the basis of SKS-20 ARK rubber extracted with the use of PDMDAACl were vulcanized more rapidly. According to [17-19] the role of vulcanization activators could belong to polymer QAS remained in the rubber after its flocculation and/or products of its interaction with the components of emulsion system.

The investigation of the flocculation of the emulsive polybutadiene (EPB) [21] showed that the consumption rate value for PDMDAACl was $8.0 \mathrm{~kg} /$ ton of rubber. At $333-353 \mathrm{~K}$ the rate value was reduced to $5.0 \mathrm{~kg} /$ ton of rubber. The change of concentration of the operation PDMDAACl solution from 2.0 to $45.0 \%$ did not have any effect on its consumption rate value. For $\mathrm{H}_{2} \mathrm{SO}_{4}$ consumption rate value $11-15 \mathrm{~kg} /$ ton of rubber a complete latex flocculation takes place. However the amount of coagulum was regularly reduced from $96-98 \%$ to 94-96 \% under decrease of $\mathrm{H}_{2} \mathrm{SO}_{4}$ consumption rate value from 10 to $9 \mathrm{~kg} /$ ton of rubber. Thus it can be concluded the process of flocculation is less sensitive to the dosage of $\mathrm{H}_{2} \mathrm{SO}_{4}$ than under the use of $\mathrm{NaCl}$ as a coagulating agent. Rubbers, rubber compounds, and vulcanizates of EPB extracted with the use of PDMDAACl and $\mathrm{NaCl}$ were equivalent by the main quality parameters. Just as in case of butadiene-styrene rubbers EPB rubber compounds were vulcanized a little more rapidly (Table 3) [21].

Similar regularities were found for latex flocculation process of butadiene-nitrile rubber SKN-26 SM with the use of PDMDAACl [16] as well as for its two fractions with mean-viscous molecular masses of $11.5 \cdot 10^{4}, 2.3 \cdot 10^{4}$, $17.4 \cdot 10^{4}$, respectively.

\subsection{PDM DAACI copolymer with sulphur dioxide}

Flocculation activity of alternative low-molecular copolymer of $\mathrm{N}, \mathrm{N}$-dimethyl-N,N-diallylammonium chloride with sulphur oxide (PDMDAACl-OS) was studied

Properties of SKS-30 ARK rubbers extracted with the use of PDMDAACl and $\mathrm{NaCl}$ as well as rubber compounds and vulcanizates based on these rubbers

\begin{tabular}{|l|c|c|}
\hline \multicolumn{1}{|c|}{ Quality performance } & \multicolumn{2}{c|}{ Flocculating agent } \\
\cline { 2 - 3 } Mass content, \% & PDMDAACl & $\mathrm{NaCl}$ \\
\hline \multicolumn{1}{|c|}{ free organic acids } & $6.3-6.8$ & 5.8 \\
\hline bound organic acids & absent & 0.15 \\
\hline \multicolumn{1}{|c|}{ antioxidant VTS-150 } & 1.3 & 1.3 \\
\hline ashes & 0.12 & 0.18 \\
\hline \multicolumn{1}{|c|}{ bound styrene } & 22.5 & 22.5 \\
\hline Mooney viscosity & 54 & 52 \\
\hline Loss of mass at 378 K, \% & 0.13 & 0.19 \\
\hline Duration of vulcanization, min & 60 & 80 \\
\hline Elastic recovery, mm & 3.0 & 3.0 \\
\hline Strain under 300 \% extension, MPa & 9.4 & 8.3 \\
\hline Toughness under extension, MPA & 27.8 & 28.8 \\
\hline Relative extension under fracture, \% & 580 & 630 \\
\hline Relative residual deformation after fracture, \% & 14 & 10 \\
\hline Rebound elasticity, \% & 40 & 42 \\
\hline
\end{tabular}


Table 3

Properties of rubbers extracted with the use of $\mathrm{NaCl}$ and flocculating agent PDMDAACl as well as rubber compounds and vulcanizates based on oil-filled EPB

\begin{tabular}{|l|c|c|}
\hline \multicolumn{1}{|c|}{ Quality performance } & \multicolumn{2}{c|}{ Flocculating agent } \\
\cline { 2 - 3 } & \multicolumn{2}{|c|}{ PDMDAACl } \\
\hline Mass content, \% & 6.0 & 5.6 \\
free organic acids & absent & 0.10 \\
bound organic acids & 0.25 & 0.25 \\
antioxidant VTS-150 & 0.12 & 0.18 \\
ashes & 0 & 15 \\
oils of PN-6K & 0.15 & 0.20 \\
\hline Loss of mass at 378 K, \% & 40 & 40 \\
\hline Mooney viscosity & 12.0 & 10.3 \\
\hline Strain under 300 \% extension, MPa & 17.7 & 18.6 \\
\hline Toughness under extension, MPa & 430 & 480 \\
\hline Relative extension under fracture, \% & 6 & 10 \\
\hline Relative residual deformation after fracture, \% & 0.37 & 0.37 \\
\hline Plasticity & & \\
\hline
\end{tabular}

for the industrial latex samples of SKS-30 ARK and EPB [23]. The completeness of the flocculation for SKS-30 ARK latex was attained at the flocculating agent supply rate of $18-20 \mathrm{~kg} /$ ton of rubber, while for EPB latex it was $14-15 \mathrm{~kg} / \mathrm{ton}$ of rubber. The introduction of the increased amount of sulphuric acid as the acidifying agent under the optimal discharge rate of PDMDAACl-OS did not have a considerable effect on the amount of the obtained coagulum. However, the influence of $\mathrm{H}_{2} \mathrm{SO}_{4}$ dosage was more significant under reduced discharge rate of the flocculating agent. For example, discharge rate of PDMDAACl-OS was almost twice reduced up to $9.0 \mathrm{~kg} / \mathrm{ton}$ of rubber for the discharge rate of sulphuric acid equal to $8.0 \mathrm{~kg} / \mathrm{ton}$ of rubber. The rubber compounds on the basis of SKS-30 ARK rubber resin extracted from the latex with the flocculating agent of PDMDAACl-OS were vulcanized more rapidly than the check sample due to the presence of the flocculating agent or the products of its interaction with the components of the emulsion system. The physico-mechanical quality indexes of the vulcanizates on the basis of SKS-30 ARK rubber correspond to the requirements of the Russian standards.

Similar regularities were observed under the flocculation of EPB latex. For the discharge rate of PDMDAACl-OS $10.8 \mathrm{~kg} / \mathrm{ton}$ of rubber completeness of the flocculation for EPB latex was attained under the discharge rate of $\mathrm{H}_{2} \mathrm{SO}_{4} 6.0 \mathrm{~kg} /$ ton of rubber. Thus, the use of PDMDAACl-OS as a flocculating agent would require its high-precision dosage.

\subsection{Poly-( $\mathrm{N}, \mathrm{N}$-dimethyl-2- oxypropyleneammonium) chloride}

Dependence of the flocculation process for SKS-30 ARK latex on the concentration of the dispersed phase in the presence of poly-(N,N-dimethyl-2-oxypropyleneammonium) chloride (PDMOPACl) was investigated in [24]. The formula of this salt is:<smiles>CCC(O)CN(C)C</smiles>

A maximum (optimal point) of flocculation was found just as in case of latexes extracted with the use of PDMDAACl. According to [24] this maximum was associated with two factors (neutralization and bridge) that can influence the flocculation mechanism. The value of the concentration of the dispersed phase in the range of $50,100,150 \mathrm{~g} / \mathrm{l}$ was insignificant in the discharge rate value of the flocculating agent.

The change of the temperature did not have any considerable effect on the process of rubber extraction from latex. Nevertheless, a slight increase of mass of the forming coagulum was observed with the increase of the temperature from 293 to $353 \mathrm{~K}$ at the initial stage of the extraction process (for low discharge rate of PDMOPACl). Decrease of PDMOPACl discharge rate from 4 to $3 \mathrm{~kg} /$ ton of rubber allowed attaining complete flocculation of SKS-30 ARK latex only at high temperatures of $353-368 \mathrm{~K}$ and discharge rate of acidifying agent of up to $30 \mathrm{~kg} /$ ton of rubber. If the discharge rate of PDMOPACl was reduced to $2 \mathrm{~kg} / \mathrm{ton}$ of rubber complete extraction of the rubber would not be achieved even at these temperatures.

The discharge rate of the acidifying agent demonstrated a greater influence on the flocculation process than the temperature and concentration of the dispersed phase in the investigated intervals. For example, 
under discharge rate of PDMOPACl $\sim 4 \mathrm{~kg} /$ ton of rubber mass of the formed coagulum was regularly increased with the increase of the introduced $\mathrm{H}_{2} \mathrm{SO}_{4}$. Coagulum mass attained $\sim 100 \%$ for the discharge rate of sulphuric acid $15 \mathrm{~kg} / \mathrm{ton}$ of rubber that proved to be the optimal technological parameters of the process.

Rubber compounds and vulcanizates did not surrender the check sample (Table 4) [24].

\subsection{Implementation of the new technology in the industry of Russia}

The performed investigations demonstrated high efficiency of the utilization of QASs as flocculating agents.
Due to its unique set of properties the most perspective one proved to be PDMDAACl. By elaborating the technological conditions for the process of rubber extraction from latex in the laboratory the following was achieved:

- PDMDAACl was proven to be a high-efficient flocculating agent for rubber latexes;

- optimal technological parameters of the flocculating process for latex were elaborated;

- application of cationic polyelectrolyte PDMDAACl has no negative effect on the properties of the obtained rubbers, rubber compounds, and vulcanizates based of these compounds.

Table 4

Properties of rubber compounds and vulcanizates on the basis of SKS-30 ARK rubber extracted with the use of $\mathrm{NaCl}$ and PDMOPACl flocculating agents and rubber resins

\begin{tabular}{|l|c|c|}
\hline \multicolumn{1}{|c|}{ Quality performance } & $\mathrm{NaCl}$ & PDMOPACl \\
\hline Mooney viscosity & 53.0 & 42.5 \\
\hline Carrer placticity, arb. un & 0.30 & 0.28 \\
\hline Recovery, mm & 1.86 & 1.84 \\
\hline Optimum of vulcanization at 416 K, min & 80 & 60 \\
\hline Conditional strain under 300\% stretching, MPa & 8.4 & 14.0 \\
\hline Conditional toughness under stretching, MPa & 27.0 & 27.6 \\
\hline Relative extension under fracture, \% & 600 & 540 \\
\hline Relative residual deformation, \% & 16 & 15 \\
\hline Rebound elasticity, \% & & \\
\hline \multicolumn{1}{|c|}{ at $293 \mathrm{~K}$} & 37 & 32 \\
\hline \multicolumn{1}{|c|}{ at 373 K } & 50 & 46 \\
\hline Shore hardness, arb. un. & 59 & 65 \\
\hline Shopper-Schlobach abrasion, $10^{-3} \mathrm{~cm} / \mathrm{m}$ & 1.80 & 1.31 \\
\hline Resistance to the growth of cuts up to $12 \mathrm{~mm}$ with a puncture, thousands of cycles & 39200 & 115200 \\
\hline Conditional toughness under stretching after ageing $(373 \mathrm{~K}, 72 \mathrm{~h})$ & 18.0 & 20.0 \\
\hline Relative extension after ageing $(373 \mathrm{~K}, 72 \mathrm{~h})$ & 242 & 257 \\
\hline
\end{tabular}

During the period of 1992-1994 the implementation of the obtained laboratory results was performed at the synthetic rubber plant, namely:

- operating modes of the industrial flocculation for SKS-30 latex were completely elaborated;

- more than 372 tons of SKS-30 rubber was produced;

- application of PDMDAACl did not require considerable changes in the technology of rubber extraction from latexes, no capital investments were needed either; mode;

- the factory treatment works operated in normal

- the produced rubber satisfied the Russian standards.

Thus, transition to the new technology of all the manufacturers of emulsion rubbers of only SKS marks in
Russia (the production volume is about 240000 tons) can significantly reduce the annual ecological damage by:

- ceasing the discharge of 100000-135000 tons of sodium chloride a year

- decreasing the amount of industrial waste discharge by $8-10 \%$ (240000 $\mathrm{m}^{3}$ per year).

\section{Conclusions}

As a result of the performed investigations the fundamental of a new exclusive ecologically reasonable industrial technology of latex flocculation for the emulsion rubbers with the use of cationic polyelectrolyte poly-N,Ndimethyl-N,N-diallylammonium chloride was elaborated. This technology was practically implemented in the Russian industry. 


\section{References}

[1] Kirpichnikov P. et al.: Khimiya i technologiya sinteticheskih kauchukov. Khimiya, Leningrad 1987.

[2] Baran A.: Dokl. Akad. Nauk Ukr.SSR, 1979, B7, 529.

[3] Verezhnikov V., Nikulin S., Misin V. and Pojarkova T.: Rus. Polym. News, 1999, 4, 36.

[4] Verezhnikov V., Kashlinskaya P. and Pojarkova T.: Colloid. Zh., 1991, 53, 822.

[5] Solomentseva I., Teslenko A., Baran A. et al:: Khimia i Tekhnologia Vody, 1983, 5, 459

[6] USSR Pat. 859377, 1065424.

[7] European Pat. 84837.

[8] Nikulin S., Verezhnikov V. et al:: Proizvodstvo i Primenenie Elastomerov, 1997, 4, 10.

[9] Nikulin S., Verezhnikov V. and Pojarkova T.: Khimicheskaya Technologia, 2005, 9, 16.

[10] Nikulin S., Verezhnikov V. and Pojarkova T.: Procs. of VI regional conf. "Problems of chemistry and chemical technology", Russia, Voronezh 1998, 3, 42.

[11] Nikulin S., Verezhnikov V. et al.: Zh.. Prikladnoi Khimii, 1999, 72, 1188

[12] Garshin A., Nikulin S. et al.: Proizvodstvo i Primenenie Elastomerov, 1994, 11, 2.

[13] Garshin A., Nikulin S. et al:: Proizvodstvo i Primenenie Elastomerov, 1995, 6, 14.

[14] Garshin A., Nikulin S. et al.: Proizvodstvo i Primenenie Elastomerov, 1994, 12, 9.

[15] Nikulin S., Verezhnikov V., Misin V. and Pojarkova T.: Trudy "Technologia. Seriya Konstrukcii iz Kompozitnyh Materialov", 1998, 3-4, 44.

[16] Verezhnikov V., Nikulin S., Pojarkova T. and Vostrikova G.: Zh. Prikladnoi Khimii, 2000, 73, 1720.
[17] Nikulin S., Verezhnikov V., Pojarkova T. and Dankovtsev V.: Kauchuki i Vulkanizaty, 2000, 5, 2.

[18] Nikulin S., Verezhnikov V., Misin V. and Pojarkova T.: Rus. Polym. News, 2002, 1, 1.

[19] Verezhnikov V., Nikulin S., Pojarkova T. and Vostrikova G.: Zh. Prikladnoi Khimii, 2002, 75, 472.

[20] Verezhnikov V., Nikulin S., Pojarkova T. and Misin V.: Ch. 10. [in:] Essential Results in Chemical Physics and Physical Chemistry. Nova Science Publishers Inc., NY 2005,

[21] Nikulin S., Verezhnikov V., Pojarkova T. and Dankovtsev V.: Zh. Prikladnoi Khimii, 2000, 73, 833.

[22] Verezhnikov V., Vostrikova G. and Pojarkova T.: Zh. Prikladnoi Khimii, 2003, 76, 1359.

[23] Verezhnikov V., Nikulin S., Pojarkova T. and Misin V.: Zh. Prikladnoi Khimii, 2001, 74, 1191.

[24] Nikulin S., Pojarkova T. and Misin V.: Zh. Prikladnoi Khimii, 2004, 77, 996 .

\section{ТЕХНОЛОГІЧНІ ТА ЕКОЛОГІЧНІ АСПЕКТИ ПРАКТИЧНОГО ЗАСТОСУВАННЯ ЧЕТВЕРТИННИХ СОЛЕЙ АМОНІЮ У ВИРОБНИЦТВІ СИНТЕТИЧНИХ ЕМУЛЬСОВАНИХ КАУЧУКІВ B POCIII}

Анотація. Розглянуто фізичні та хімічні аспекти $i$ технологічні параметри виробництва каучуків з промислового латексу із застосуванням галогенідів амонію, тетраалкіламонієвих солей, полі (N,N-диметил-2-оксипропіленамоній)хлориду, полі-N,N-диметил-N,N-діаліламоній хлоридута його кополімеру $3 \mathrm{SO}_{2}$. Показано важливий екологічний вплив полімерних флокулянтів.

Ключові слова: четвертинні солі амонію, каучук, латекс, флокулянт, екологія. 